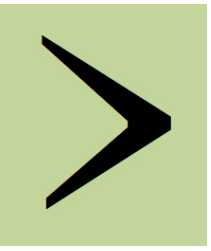

\author{
Papers in Historical Phonology \\ http://journals.ed.ac.uk/pihph \\ ISSN 2399-6714 \\ Volume 2, 116-151 \\ DOI : $10.2218 /$ pihph.2.2017.1910
}

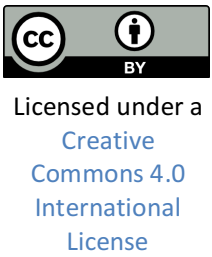

\title{
Voice-induced vowel lengthening
}

\author{
TOBIAS SCHEER \\ Université Côte d'Azur, CNRS
}

\begin{abstract}
Vowels are longer before sonorants and voiced obstruents than before voiceless obstruents. This pattern is found in many languages and by some is argued to be universal. In some languages it has been phonologized and gives rise to alternations. Three cases are examined: Western Slavic, English and German. In all cases, I argue that the mechanism which modifies vowel duration in a voiced context is phonetic in kind (not phonological), and involves voice-induced lengthening, rather than so-called 'pre-fortis clipping'. Phonetic length can be phonologized by its inscription into the lexical recording of morphemes. Phonological processes such as (Canadian) raising in English or oo > uu raising in Western Slavic may then take this lexical length as an input. This analysis allows us to keep spontaneous and nonspontaneous voicing truly separate: voicing in sonorants and vowels is never phonologically active, its spreading can only occur in the phonetics ('passive voicing' in Laryngeal Realism). A strong argument in favour of this view is the fact that cross-linguistically sonorants appear to always be among the triggers of voice-induced vowel lengthening: there are no cases where vowels lengthen before voiced obstruents, but not before sonorants. This is predicted if lengthening is phonetic, but unexpected if it were phonological: the phonologically active voicing of obstruents should at least sometimes be the only trigger.
\end{abstract}

\section{Phonological specification of voicing in sonorants and vowels?}

So-called Cracow voicing (or Cracow-Poznań voicing) is a well-studied phenomenon (Bethin 1984, 1992, Gussmann 1992, Rubach 1996, Cyran 2011, 2012, 2014) whereby word-final voiceless obstruents (as in jak 'how') are voiced when the following word begins with a voiced obstruent (ja[g] dobrze 'how well'), a sonorant (ja[g] możesz 'how can you') or a vowel (ja[g] oni 'how they').

This is unexpected given the distinction between spontaneous voicing (in sonorants and vowels) and non-spontaneous voicing (in obstruents) (Chomsky \& Halle 1968, 300f): the non-phonological 
character of voicing in sonorants and vowels, as opposed to phonologically controlled voicing in obstruents, sits on a solid empirical record that is consensual in all phonological quarters. ${ }^{1}$ For example, sonorants and vowels do not undergo final devoicing because their voicing is phonologically irrelevant, while the voicing of obstruents is subject to manipulation by phonological processes. Hence sonorants and vowels should be unable to transmit their voicing to obstruents which they do, however, in Cracow voicing.

The Cracow voicing pattern is not isolated: it occurs in a number of other languages (always in external sandhi) such as Catalan (Wheeler 1986, Bermúdez-Otero 2006), West Flemish (De Schutter \& Taeldeman 1986), Breton (Krämer 2000) and Durham English (Gussenhoven \& Jacobs 2011: 196). Beyond this specific pattern, cases where sonorants (and vowels) appear to have phonologically active voicing are documented by, among others, Rice \& Avery (1989), Piggott (1992), Rice (1993), Avery \& Idsardi (2001) and Clements \& Osu (2002, 338). Botma (2011) provides a comprehensive overview of the issues at hand.

The standard analysis (on which more in section 2 below) introduces the voicing of sonorants and vowels into the phonological representation of these segments, and then allows for it to be subject to phonological computation. In what follows, it is first recalled that there is an alternative analysis, due to Cyran (2014) and based on Laryngeal Realism, whereby the transmission of voicing does not occur in the phonology but is phonetic in kind. On this view sonorants and vowels are never phonologically specified for voice. In a second step, a different phenomenon is introduced where like in Cracow voicing the voicing of sonorants has phonological consequences, although it is not transmitted to obstruents: vowel lengthening before voiced obstruents and sonorants. This pattern is illustrated by a case found in Western Slavic which has the peculiarity that vowels are lengthened by following sonorants and voiced obstruents only if these are word-final. Remnants of this process are the o- $u$ alternations in Polish and Czech (nóż / nůž [nuf] noż-e / nož-e [nэzє] 'knife Nsg, Gsg') and nasal vowel alternations in Polish (ząb [zomp] zęb-u [zembu] 'tooth Nsg, Gsg').

I show that the alternations found in the modern languages are erratic in the sense that they concern only an arbitrarily defined subset

\footnotetext{
1 The distinction is also at the origin of the largely consensual idea that the 'natural' (or unmarked) state of sonorants and vowels is to be voiced, while the archetypical obstruent is voiceless. This view is also supported by evidence from first language acquisition: children acquire voiceless before voiced obstruents (e.g. Major \& Faudree 1996, 71).
} 
of the words that qualify in terms of their phonological properties (and also, conversely, words which lack these properties do alternate). Given this picture, the oldest record of the two languages at hand, Old Polish and Old Czech, is examined: albeit to a lesser extent, it shows the same lexical idiosyncrasy.

The question then is whether there was a diachronic stage where the alternations were regular: this could have been the case sometime between the onset of dialectalization of Common Slavic and Old Polish / old Czech. The area where traces of voice-induced vowel lengthening are recorded goes beyond these two languages, or Western Slavic: it concerns an ill-defined Western area of the Slavic territory (including the westernmost languages of South Slavic, Slovenian and SerboCroatian) that transcends standard classification (see section 4.1). The alternations are irregular in all languages for which we have written records.

I argue below that there was no diachronic stage where the alternations at hand were regular as a phonological process. Rather, regularity was only ever phonetic, and the written record does not indicate phonetic lengthening. Spelling only reacts when phonetic variation is phonologized and produces category-changing, i.e., phonemic alternations. This occurred at the latest when phonetic length was converted into vowel height in Western Slavic: long oo was raised to uu (but short o remained unchanged), and in Polish short ą was fronted to ę (while long ąą was not modified).

Following this scenario, the original phonetic trigger was carried into phonology through the phonologization of phonetic length in the lexical entries of individual lexical items, rather than by devising a phonological process o $\rightarrow u$ / __ $\mathrm{C}_{+ \text {voice }}$ \#. Such a process, I contend, was never present in the synchronic phonological computation of any diachronic stage. That is, the conversion of gradient phonetics into modifications of discrete units occurred only in the lexicon. This is the source of the arbitrary lexical coverage: lexical conversion does not follow any rule. The alternations, once phonological in kind, are then (synchronically) managed by allomorphy (or maybe suppletion) within inflectional paradigms. Given modern Polish rzad $\sim$ rzęd-u 'row Nsg, Gsg'2 and rząd rzq̨d-u 'government Nsg, Gsg', two allomorphs are stored for 'row', /rząd/ and /rzęd/, while only one stem form is devised

\footnotetext{
2 The following abbreviations are used in this paper: Nsg = nominative singular, Asg = Accusative singular, Gsg = genitive singular, Lsg = locative singular, Isg = instrumental singular, $\mathrm{Gpl}=$ genitive plural, $\mathrm{Dpl}=$ dative plural, masc. $=$ masculine, fem. $=$ feminine, neut. $=$ neuter, poss. $=$ possessive, pres. $=$ present tense, pret. $=$ preterite, part. $=$ participle.
} 
for 'government', /rząd/. In the case of 'row', /rząd/ is selected in Nsg and Asg, /rzęd/ elsewhere. In Old Polish and Old Czech where the alternations were slightly more regular but just as unpredictable, the same allomorphic (or suppletive) workings were in place.

The workings proposed thus represent a case where a step in the life cycle of phonological processes is skipped: instead of going through a stage where the alternation is managed by phonological computation, it moves directly from the phonetics into the lexicon.

Finally, the extra condition concerning the right word edge that is found in the Western Slavic pattern looks like a truly phonological factor. How could vowel lengthening be phonetic in these circumstances, i.e. when it occurs only before word-final (voiced) consonants? It turns out that this pattern may also be produced by the phonetics: in English, $\mathrm{V}_{\mathrm{x}}$ in $\mathrm{CV}_{\mathrm{x}} \mathrm{C} \#$ is significantly longer in duration than it is in $\mathrm{CV}_{\mathrm{x}} \mathrm{CV \#}$ (Klatt 1973).

On a more general note, the article concludes that it does not make sense to duplicate in the phonology what phonetics provides for anyway. Vowel lengthening before voiced obstruents and sonorants occurs in many languages: it is well documented in the phonetic literature and possibly universal (Chen 1970, Delattre 1962, Maddieson 1996, 164f, 1999). If this process were ever due to phonological computation, one would expect it to have implementations where only voiced obstruents, but not sonorants, produce the effect. This should actually be the default case given what we know about obstruent and sonorant voicing. It appears that this pattern is absent from the empirical record, however. This makes a strong argument against the ability of voiced obstruents (and of course also of sonorants) to determine vowel length through phonological computation.

The roadmap is as follows. Section 2 introduces the standard view assuming that sonorant voicing may be represented in phonological representation and manipulated by phonological computation. In section 3, this option is contrasted with the alternative entertained in Laryngeal Realism where voice transmission occurs in the phonetics (passive voicing). Section 4 looks at the Western Slavic alternation in both diachronic and synchronic detail, and section 5 discusses a parallel case found in German strong verbs. The well-known English pattern of voice-induced vowel lengthening is introduced in section 6 , followed by a perspective on phonologization that skips the stage where the pattern is managed by phonological computation. Finally, concluding remarks in section 8 make the point that all cases in the large record of voiceinduced vowel lengthening appear to be triggered by both voiced obstruents and sonorants (no cases where only the former are triggers seem to be on record). 


\section{Obstruents voiced by sonorants and vowels in the phonology}

The standard way of expressing the phonological relevance of voicing in sonorants and vowels is laid out in Rice (1993): there are two distinct (phonological) primes, [voice] and [sonorant voice]. The former is found only in obstruents, while the latter is present in sonorants and vowels as well as in certain obstruents - in those, precisely, whose voicing interacts with sonorants and vowels. Rice (1993) coined the term sonorant obstruent for these. Voicing in sonorants and vowels can then be transmitted to (sonorant) obstruents simply by spreading [sonorant voice]. There is also an Element-based version of this take: Botma (2004, 56f) argues that L is the head in sonorants, but only an operator in sonorant obstruents (also Botma \& Smith 2006). Honeybone $(2002,232,2005)$ also uses unary primes but happily implements laryngeal specifications into sonorants (which are then spread onto obstruents).

Another way of making both types of voicing distinct in principle but combinable in the phonology when needed is proposed by Itô \& Mester $(1986,59 f)$. In their account, there is only one feature [ \pm voice]. Redundant values of this feature are absent lexically and only come into being at the end of the derivation by default-filling. Since [+voice] is redundant for sonorants, it is absent until the end of the derivation and therefore cannot be spread to obstruents. Obstruents on the other hand are unspecified for [-voice], which is only filled in by default when no voice value is present at the end of the derivation. This makes spontaneous and non-spontaneous voicing waterproof (only obstruents are lexically specified for [voice]), but modifying the stage in the derivation (in a rule-ordering environment) where default filling of redundant features occurs will allow for both worlds to interact. Hence if [+voice] is filled into sonorants before the end of the derivation and a voice assimilation rule applies after that, the voicing of sonorants will be able to spread to obstruents. Default filling of [+voice] into sonorants is also an ingredient of Bethin's (1992) and Rubach's (1996) analyses of Cracow voicing.

These approaches uphold the distinction between spontaneous and non-spontaneous voicing in one way or another (distinct features, lexical presence vs. absence of a feature), but allow for sonorants and vowels to be phonologically specified for voicing, and this voicing then undergoes phonological computation. In other words, there are two types of voicing which in principle both qualify for participating in phonological computation but usually do not mix. On some occasions, though, they do. 


\section{Obstruents voiced by sonorants and vowels in the phonetics: Laryngeal Realism, modular spell-out}

An alternative view is expressed by Cyran (2011, 2012, 2014) and Scheer $(2015 a, b)$ : sonorants and vowels never bear any phonological specification for voicing, and their voicing is never taken into account by phonological computation. Since they do impact on obstruents, however, the communication with other segments can only be phonetic in kind: at the phonetic level there is only one type of voicing (voicing of obstruents, sonorants and vowels is the same), and hence sonorant/vowel voicing can influence obstruents.

The difference between phonetic and phonological voicing has been central since the 90s when it was understood that there are two types of laryngeal systems: ${ }^{3}$ one where voiced obstruents are phonologically specified as such (while voiceless obstruents have no phonological specification), another where voiceless obstruents bear a phonological instruction to be voiceless (while voiced obstruents are phonologically unspecified for voicing). This insight is known as Laryngeal Realism (Harris 1994, Iverson \& Salmons 1995, Avery \& Idsardi 2001, Honeybone 2002, 2005, Ringen \& Kulikov 2012): it requires two distinct and privative (i.e. non-binary) primes responsible for voicing, [voice] and [spread glottis] in feature systems, L and $\mathrm{H}$ when unary primes are used. L/[voice] provide a phonological instruction for voicing, while $\mathrm{H} /[$ spread glottis] impose phonologically controlled voicelessness. In two-way laryngeal systems, then, only one prime is used: voicing languages such as Romance and Slavic only have $\mathrm{L} /[$ voice], while in (so-called) aspiration languages such as Germanic only $\mathrm{H} /[$ spread glottis] occurs.

In both systems, the category that has no phonological specification for laryngeal behaviour is called neutral, transcribed here as $\mathrm{C}^{\circ}$. Hence voicing languages oppose $\mathrm{C}^{\mathrm{L}}: \mathrm{C}^{\circ}$, while aspiration languages contrast $\mathrm{C}^{\mathrm{H}}: \mathrm{C}^{\circ}$. While the pronunciation of the actively specified categories $\mathrm{C}^{\mathrm{L}}$ and $\mathrm{C}^{\mathrm{H}}$ is commanded by the phonology and hence does not vary, the voicing of the neutral consonants $\mathrm{C}^{\circ}$, escaping phonological control, is a matter of contextual and/or systemic properties. Languages using $\mathrm{H} /$ [spread glottis] are called aspiration languages since often $\mathrm{C}^{\mathrm{H}}$ is not only pronounced voiceless, but also aspirated. This then allows $\mathrm{C}^{\circ}$ to not take on any contextual voicing, and the result is a language like

\footnotetext{
3 The neogrrammarians already were aware of this fact: Sievers (1901: §181) writes that "on the other hand it needs to be admitted that there are languages that oppose voiceless sounds of different strength. The Swiss for example distinguish the syllables pa and ba, ta and da based on a stronger pressure on p,t, which is weaker on b,d. But both types of sounds are voiceless." For more detail see Scheer \& Ségéral (2016).
} 
Danish (or the Swiss variety described by Sievers in note 3) where the surface contrast is between voiceless aspirated $\left(\mathrm{C}^{\mathrm{H}}\right)$ and voiceless nonaspirated $\left(\mathrm{C}^{\circ}\right)$ obstruents. In other systems $\mathrm{C}^{\mathrm{H}}$ may be spelt out without aspiration, a fact that forces $\mathrm{C}^{\circ}$ to take on some voicing from the phonetic environment in order for the two series to be distinct on the surface. Since this voicing comes from the phonetic environment and is not controlled by the phonology, it is called passive voicing. Aspiration and passive voicing in individual $\mathrm{H} /$ [spread glottis] languages may also be contextually distributed: in English for example, $\mathrm{C}^{\mathrm{H}}$ is aspirated word-initially and before stressed vowels, but unaspirated elsewhere. This gives leeway for word-initial $\mathrm{C}^{\circ}$ to be more or less passively voiced, while $\mathrm{C}^{\circ}$ needs to be passively voiced in contexts where $\mathrm{C}^{\mathrm{H}}$ is nonaspirated in order to guarantee a surface distinction. This produces a situation where word-initial $\mathrm{C}^{\circ} \mathrm{S}$ are voiced to different extents across dialects.

Laryngeal Realism shows two things that are relevant for the analysis of cases where the voicing of sonorants and vowels interacts with other segments.

(1) Consequences of Laryngeal Realism

a. there is a language-specific, idiosyncratic and unpredictable relationship between phonological categories and the way they appear on the surface $\left(\mathrm{C}^{\mathrm{H}}\right.$ may or may not be pronounced as aspirated)

b. the phonetic voicing of obstruents may be phonological $\left(\mathrm{C}^{\mathrm{L}}\right.$ in $\mathrm{L} /[$ voice] languages) or passive (i.e., phonetic, in $\mathrm{H} /[$ spread glottis] languages) in kind; when passively voiced, obstruents do receive voicing from sonorants and vowels, but this transmission occurs in the phonetics and has nothing to do with phonology

(1a) is called phonetic interpretation in Government Phonology (Harris \& Lindsey 1995, 46ff, Harris 1996, Gussmann 2007, 25ff). Phonetic interpretation is the idea that sound patterns may not only be due to phonological and phonetic regularities, but also to a list-type relationship that relates phonological and phonetic categories upon conversion of the former into the latter. For example, the classical analysis of the fact that in Polish some $e$ 's palatalize (Lsg $-e$ as in lot loci-e 'flight Nsg Lsg') while others do not (Isg -em as in lot $\sim$ lot-em 'flight Nsg Isg') is phonological. That is, the $-e$ of the Isg morpheme is front on the surface, but not underlyingly (Rubach 1984): the morpheme identifies as /-rm/ lexically and therefore does not cause palatalization. It is turned into /-em/ by a (context-free) phonological 
rule at the appropriate derivational stage, i.e., after palatalization has applied.

Instead of having the job done by phonological computation, the phenomenon may also be viewed as purely interpretational: like Rubach, Gussmann $(2007,56 \mathrm{ff})$ holds that there are two distinct items in Polish that appear as $[\varepsilon]$ on the surface, palatalizing I-A that occurs in Lsg and non-palatalizing _-I-A that is found in Isg (heads are underscored and ', is an empty head). These are distinct in the lexicon and remain unaltered during phonological computation. Phonetic interpretation then converts the output of phonology into phonetic objects. The conversion works like in a multi-lingual dictionary (because phonological and phonetic items belong to two distinct sets of vocabulary, just like words of two distinct languages): it is unpredictable (there is no reason why, say, English table has the Polish equivalent stół rather than dom) and thus conventional and arbitrary. Equivalences are language-specific and thus part of the systemic settings of each language (in the structuralist sense). They are stored in long-term memory and must therefore be learned in the same way as inventories. The specific Polish convention is that the two phonological objects I-A and _-I-A are spelt out as the same phonetic object $[\varepsilon]$ — in other words, the phonological contrast is neutralized in pronunciation. On this analysis, the neutralization of the lexical contrast (/e/ vs. / $\mathrm{\gamma} /$ for Rubach, I-A vs. _-I-A for Gussmann) is not enacted by phonological activity: phonology does not know (or care) how the items it manipulates end up being pronounced. Rather, the neutralization is interpretational in kind, i.e., it occurs post-phonologically when phonological vocabulary is converted into phonetic items.

In a modern modular environment where the same interface mechanisms govern the conversion of morpho-syntactic into phonological vocabulary (upper interface) and the translation of phonological into phonetic items (lower interface), phonetic interpretation is a spell-out operation (just like the conversion of, say, 'past tense' into -ed in English is due to spell-out). The modular perspective holds that the conversion (at both interfaces) involves the same matching of lists ('past tense' $\leftrightarrow$-ed, I-A $\leftrightarrow[\varepsilon]$ ), and hence is noncomputational. As a consequence, the match of phonological and phonetic items is arbitrary (Boersma 1998, Hamann 2011, 2014). This modularity-based take on the phonology-phonetics interface is discussed in Scheer (2014). 


\section{Western Slavic vowel lengthening before sonorants and voiced obstruents}

\subsection{Old Czech and Old Polish}

When word-final yers were lost, languages in the Western area of the Slavic territory lengthened the preceding vowel. Vowel lengthening is recorded for Western Slavic (except for Lower Sorbian) as well as the westernmost languages of South Slavic (Serbo-Croatian and Slovenian). Given that the process seems to relocate the vocalic unit that disappears on the preceding vowel by making it long, it is traditionally described as compensatory lengthening. The process in its various guises, its geographic extension and possible restrictions to a subset of vowels is described e.g. in Bethin (1998, 96ff), Timberlake (1983a,b), Kavitskaya (2002, 119ff), Shevelov (1964, 447f), Carlton (1991, 215ff), Vondrák (1924, 309-320), Rospond (1979, 65ff), Stieber $(1973, \S \S 38-$ 43) and Sanders (2003, 57ff). In all languages where it occurs lengthening is irregular, covering only an unpredictable subset of the words that offer the triggering context. Sometimes also words that should not undergo the process do display lengthening. This is true for all diachronic stages of the languages at hand, including the oldest record available. Given its geographical extent, lengthening is assumed to have occurred in late Common Slavic (CS).

Some illustration is provided under (2) below, where the Nsg marker of masculines is used: the loss of CS - $\mathrm{b}$ produces length on the preceding vowel (in Old Czech and Old Polish length is marked by an acute accent), while markers such as Gsg were regular vowels in CS that were not lost and hence did not trigger any modification.

(2) Slavic: vowel lengthening after the loss of final yers

\begin{tabular}{|c|c|c|c|c|c|c|}
\hline CS & $\begin{array}{l}\text { Nsg } \\
\text { dol-ъ }\end{array}$ & $\begin{array}{l}\text { Gsg } \\
\text { dol-u }\end{array}$ & $\begin{array}{l}\text { Nsg } \\
\text { bog-ъ }\end{array}$ & $\begin{array}{l}\text { Gsg } \\
\text { bog-a }\end{array}$ & $\begin{array}{l}\text { Nsg } \\
\text { most- }\end{array}$ & $\begin{array}{l}\text { Gsg } \\
\text { most-u }\end{array}$ \\
\hline \multirow{4}{*}{$\begin{array}{l}\text { Old Polish } \\
\text { Old Czech } \\
\text { Serbo-Croatian }\end{array}$} & dół & doł-u & & & most & most-u \\
\hline & dól & dol-u & bóh & boh-a & most & most-u \\
\hline & & & bôg & bòg-a & môst & mòst-a \\
\hline & 'dale, & valley' & 'God' & & 'bridge' & \\
\hline
\end{tabular}

It is unclear, though, whether there is really a causal relation between the dropping of final yers and the lengthening observed. Shevelov $(1964,447)$ says that the lengthening is "customarily called compensatory": the facts could as well be covered by saying that vowels lengthen before word-final consonants. Carlton (1991, 217-219) and Sanders $(2003,60 \mathrm{f})$ discuss reasons to doubt the compensatory 
causality for Western Slavic. Whatever the initial trigger of the lengthening, Stieber $(1973, \S 41)$ demonstrates that in $15^{\text {th }}$ century Polish there was an active process in the language that lengthened vowels before word-final (voiced, see below) consonants: loans that were present then (but absent when yers were lost long before the $15^{\text {th }}$ century) appear with a lengthened vowel, e.g. Adaam, 'Adam', staal 'steel', captuur 'hood', qhaan (modern spelling: chaan) 'khan'. Hence at least in Old Polish the position before a word-final consonant (not the loss of a following vowel) is responsible for lengthening.

Crucial for our purpose is that in Polish and Czech (but also Lower Sorbian and probably members of Lechitic other than Polish, i.e., Polabian and Kashubian), lengthening only occurred if the final consonant was either a voiced obstruent or a sonorant. The pattern may thus be described as under (3). Note that here and below data are restricted to the vowel 0 , which of all vowels is most inclined to undergo lengthening. ${ }^{4}$

(3) $0>00 /{ }_{-} \mathrm{C}_{+ \text {voice }} \#$ where $\mathrm{C}_{+ \text {voice }}=$ sonorants and voiced obstruents

Illustration for Old Czech is provided in (4) where lengthening occurs in bóh (before a voiced obstruent) and dól (before a sonorant), but not in rok (before a voiceless obstruent). ${ }^{5}$ Note that $\mathrm{R}$ is shorthand for sonorants, D for voiced and T for voiceless obstruents.

\footnotetext{
${ }^{4}$ The situation of this vowel is also easier to assess since (like e) it was always short in CS. Hence long o post-CS languages can only be the result of lengthening: there is no original long oo, which would have occurred before any consonant.

5 The Western Slavic situation is described by Pedersen $(1905,305)$ and Vondrák $(1924$, 309-320), Old Czech and its further development is discussed in Gebauer (1963 [1894], §502c), Hujer (1946, 93f), Komárek (1969, 73f, 1982, 30f) and Trávníček (1935, §§259261), while the Old Polish pattern is presented in Stieber $(1958,17 f, 1973, \S 38 f)$, Klemensiewicz et al. (1964, 52f), Rospond (1979, 65ff) and Długosz-Kurczabowa \& Dubisz (1993, 79ff). Glosses of the words mentioned, line by line: _D 'God', 'leg/foot', 'angle', 'nose', 'water', 'haystack/pile', 'vehicle', 'word', 'bean', 'possessive suffix', 'hunt', 'dative masc./neut. suffix', 'metal', 'birth/breed'. _R 'table', 'mountain', 'pine wood', 'courtyard', 'school', 'thunder', 'me (strong pronoun)', 'tree', 'house', 'quarry', 'salt', 'bell', 'ox', 'hunt', 'half', 'fight', 'dung'. _T 'year', 'pellet', 'step', 'flux'.
} 
(4) Old Czech

Lengthening before word-final sonorants and voiced obstruents

\begin{tabular}{|c|c|c|c|c|c|c|}
\hline & & ternatin & roots & & non-alte & nating roots \\
\hline & Nsg & hasc. & Gpl f & 1./neut. & & masc. \\
\hline & Nsg & Gsg & Nsg & Gpl & Nsg & Gsg \\
\hline _D & bóh & boh-a & noh-a & nóh & roh & roh-u \\
\hline & nóž & nož-ĕ & vod-a & vód & stoh & stoh-u \\
\hline & vóz & voz-u & slov-o & slóv & bob & bob-u \\
\hline & poss. -óv & -ova & & & lov & lov-u \\
\hline & Dpl -óm & & & & kov & kov-u \\
\hline & & & & & rod & rod-u \\
\hline _R & stól & stol-u & hor-a & hór & bor & bor-u \\
\hline & dvór & dvor-a & škol-a & škól & hrom & hrom-u \\
\hline & mój & moj-ĕ & & & strom & strom-u \\
\hline & dóm & dom-u & & & lom & lom-u \\
\hline & sól & sol-i & & & zvon & zvon-u \\
\hline & vól & vol-u & & & hon & hon-u \\
\hline & pól & pol-u & & & boj & boj-ĕ \\
\hline & hnój & hnoj-ĕ & & & & \\
\hline$-\mathrm{T}$ & rok & rok-u & & & & \\
\hline & brok & brok-u & & & & \\
\hline & krok & krok-u & & & & \\
\hline & tok & tok-u & & & & \\
\hline
\end{tabular}

As was mentioned, the alternation is far from covering the entire lexicon in Old Czech. There are exceptional items both ways: those where the triggering environment is met but which do not show lengthening (roh $\sim$ roh-u, bob $\sim$ bob-u, stoh $\sim$ stoh- $u$, bor $\sim$ bor-u), and those where lengthening should not occur because the following sonorant or voiced obstruent is not word-final: hróz-a 'scare, creeps', stvór-a 'creature', mór-a 'moth', smól-a 'bad luck'. These cases are usually explained by analogy. Note that it is still true that the root-final consonant of the latter items is voiced: their Gpl forms hróz, stvór, mór, smól instantiate the context for lengthening, and the lengthened form may then have been lexicalized. ${ }^{6}$

\footnotetext{
${ }^{6}$ It seems that there is only one word in Old Czech where lengthening occurs before a (word-final) voiceless obstruent: póst post-u 'fasting Nsg, Gsg' (> modern Czech půst půst-u).
} 
The situation is about the same in Old Polish: the root vowel is lengthened before final voiced obstruents (but not before vowel-initial inflectional markers) for example in bóg 'God', bób 'broad bean', róg 'horn', nóż 'knife', wóz 'car', miód 'honey', wróg 'enemy', chłód 'chill', gród 'borough', żłób 'manger' and final sonorants as in dół 'pit', stół 'table', sól 'salt', dwór 'court', mój 'me (strong pronoun)', król 'king', tchórz 'polecat'. When comparing Old Czech and Old Polish, the incomplete and unpredictable coverage of the lexicon is illustrated: the aforementioned Old Czech roh $\sim$ roh- $u, b o b \sim b o b-u$ should have lengthened but did not, while in Old Polish they did: róg rog-u, bób $b o b-u$. On the other hand, Old Polish dom $\sim$ dom- $u$ should have lengthened but did not, but Old Czech displays regular dóm $\sim$ dom-u.

Finally, note that Old Polish had (only) one nasal vowel, nasal o (written <ą>), which also underwent lengthening before word-final

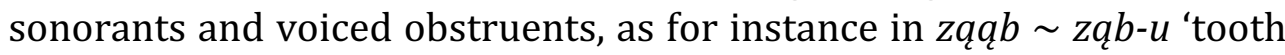
Nsg, Gsg' (Stieber 1973, §35, Carlton 1991, 128f).

\subsection{Further evolution in the modern languages}

The developments shown in (5) below have occurred since Old Czech and Old Polish. They have further obscured the already irregular pattern, to the effect that the alternations in Modern Czech and Modern Polish are entirely unpredictable and lexicalized. Since Old Czech and Old Polish, analogy has worked in both ways, levelling out alternations where they are rightful (for example in Gpl forms in Czech: $\mathrm{OCz}$ vod- $a$ vód 'water Nsg, Gpl' > MCz vod-a vod) and creating them where they have no etymological grounds (e.g., before voiceless consonants in Polish as in sobot-a sobót 'Saturday Nsg, Gpl', powrót powrot-u 'return Nsg, Gsg' etc.).

The modern situation with all its ins and outs is described by Bethin (1979, 253f, 259), Gussmann (1980, 53f, 113ff, 2007, 261ff), Szpyra (1989, 160ff, 1992, 288ff) and Grzegorczykowa (1999, 114ff) for Polish and by Trávníček $(1951, \S 12)$ for Czech.7

7 The situation of Polish nasal vowels is specifically discussed in Gussmann (1980, 54, 84ff, 2007, 269ff), Rubach (1984, 130ff, 229f), Szpyra (1989, 163ff, 1995, 104) and Bethin $(1992,62 \mathrm{ff})$. 
(5) Developments since Old Czech / Old Polish

\begin{tabular}{|c|c|c|}
\hline & Czech & Polish \\
\hline 1. final dev & 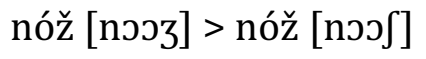 & nóż [nכoz] > noż [nכJ] \\
\hline 2. raising oo $>$ uu & nóž [nכJ]] > nůž [nuuf] & nóż [nכJ]] > nóż [nuu $]$ \\
\hline 3. short ą > ę & 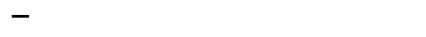 & ząb-u > zęb-u \\
\hline
\end{tabular}

In addition, Polish has lost distinctive vowel length. In Czech where vowel length is still distinctive today, [0] thus alternates with [uu] (spelt

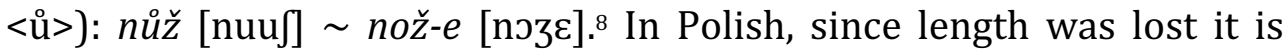
only because of the raising oo $>$ uu that the alternation is still visible: long [э] is [u] today (spelt <ó>), while short [0] is unchanged, to the effect that nóz [nuf] alternates with noż-a [nэza]. The same goes for the nasal vowels: the short-long contrast is only preserved because the short nasal vowel became front. As a result, the alternation type ząb [zomp] zęb-u [zembu] 'tooth Nsg, Gsg' occurs.

Note that in both languages final devoicing has obliterated the surface trigger: final voiced obstruents are no longer voiced on the surface. Hence a phonetic account based on surface voicing is out of the question. It is also ruled out since in the modern languages the alternation involves a category change: $\mathrm{o}$ and $\mathrm{u} / \mathrm{uu}$ are different phonemes (unlike the original short-long distinction).

Category changes in the modern languages can thus only be due to phonological patterning. But even in Old Czech and Old Polish, the unpredictable lexical idiosyncrasy strongly suggests that the alternation was always lexicalized, from day one: a process like (3) was never carried out by phonological computation. Rather, phonetic length was phonologized through a modification of the lexical entry (restructuring). Synchronic alternations in inflectional paradigms (in the old and modern languages) are then the result of the introduction of vowel length just in the form where it occurred (Nsg and Gpl) without this affecting other forms. In other words, there was no common underlier anymore in these cases, but rather two allomorphs. Table (6) below contrasts an instance of this restructuring (bůh 'God') with a

8 There are only 20 roots left that display the alternation, with long vowels only in Nsg: hnůj hnoje 'dung', lioj loje 'suet', můj moje 'me (strong pronoun)', tvůj tvoje 'you (strong pronoun)', svůj svoje 'his/her (strong pronoun)', stůj stojím 'stand, imperative, 1st sg', stůl stole 'table', sůl soli 'salt', důl dolu 'valley', hůl hole 'stick', kůl kolu kůlu 'picket', půl polovina 'half', vůl vola 'ox', dům domu 'house', kůň konĕ 'horse',

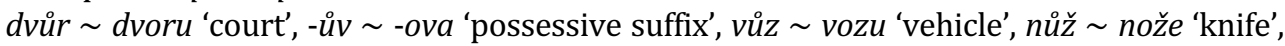
bůh bohu 'God'. 
word where phonetic length was not lexicalized (roh 'angle')9

(6) Genesis of lexical idiosyncrasy in Old Czech

\begin{tabular}{|c|c|c|c|c|}
\hline & \multicolumn{2}{|c|}{ phonetic length lexicalized } & \multicolumn{2}{|c|}{ phonetic length not lexicalized } \\
\hline & Nsg & Gsg & Nsg & Gsg \\
\hline $\begin{array}{l}\text { phonetic } \\
\text { lengthening }\end{array}$ & $/$ bog/ $\rightarrow$ boog & /bog-a/ $\rightarrow$ boga & $/ \mathrm{rog} / \rightarrow \operatorname{roog}$ & $/$ rog-u/ $\rightarrow$ rogu \\
\hline Old Czech & /booh/ $\rightarrow$ booh & /boh-a/ $\rightarrow$ boha & $/$ roh/ $\rightarrow$ rooh & $/$ roh-u/ $\rightarrow$ rofu \\
\hline $\begin{array}{l}\text { final } \\
\text { devoicing }\end{array}$ & /booh/ $\rightarrow$ boox & /boh-a/ $\rightarrow$ boha & $/$ roh/ $\rightarrow$ roox & /roh-u/ $\rightarrow$ rohu \\
\hline $\begin{array}{l}\text { raising } \\
\mathrm{oo} \rightarrow \mathrm{uu}\end{array}$ & /buuh/ $\rightarrow$ buux & /boh-a/ $\rightarrow$ boha & $/$ roh $/ \rightarrow \operatorname{rox}$ & /roh-u/ $\rightarrow$ rohu \\
\hline Mod. Czech & bůh [buux] & boha [boha] & $\operatorname{roh}[\mathrm{rox}]$ & rohu [rofu] \\
\hline
\end{tabular}

Given this situation, the modern alternations are lexicalized, i.e., managed by allomorphy (or suppletion): two lexical items are associated to the meaning 'God' in Modern Czech: /buuh/ and /boh/. The former is selected in Nsg and Asg contexts, while the latter appears elsewhere. On the other hand, there is just one lexical item associated to 'angle': /roh/.

\subsection{A once regular phonological process?}

While it would be hard to make a case for the modern situation being managed by a phonological or phonetic regularity, a phonological process such as that in (3) can be argued to have existed when the alternation was originally innovated. Following the life cycle of phonological processes (Baudouin de Courtenay 1895, Vennemann 1972, Bermúdez-Otero 2015), the innovation of such a process is achieved by phonologizing an existing phonetic pattern. Given its phonetic origin, the phonological process is completely regular at first and may then acquire morphological and lexical conditions. On this perspective, the Old Czech and Old Polish situation represents an already advanced stage in the life of the original vowel lengthening where alternations are lexicalized. As was mentioned above, the process is thought to have been innovated in late Common Slavic,

\footnotetext{
${ }^{9}$ Note that there is no phonetic length due to following word-final voiced consonants left in the modern language since it was either phonologized and now is a long /uu/, or undone by final devoicing: the stem-final consonant of roh is still underlyingly voiced, but voiceless on the surface in roh [rox]. If the workings of the modern phonetics resembled the original state of affairs, surface length should still be present before stem-final sonorants (which do not undergo final devoicing) in words like výbor výbor-u where phonetic length was not lexicalized.
} 
where according to the life cycle perspective it would have been regular and phonological in kind.

This scenario takes for granted that the rule under (3) is a possible phonological process. Its critical ingredient is the reference to the voicing of sonorants. If sonorant and vowel voicing are never phonologically active and hence cannot be manipulated by phonological computation, (3) is not a possible phonological process and the old Czech / Old Polish pattern that was already fully lexicalized needs to be accounted for by a different scenario.

The alternative analysis builds on a regular phonetic pattern where vowels are lengthened before word-final sonorants and voiced obstruents. It is shown in section 7.3 that the phonetics is indeed able to generate such a pattern where vowels are lengthened more before word-final sonorants and voiced obstruents than they are before these consonants elsewhere: this situation is documented for contemporary English. This phonetic pattern is then phonologized, albeit not in terms of phonological computation but rather directly into the lexical entries of morphemes. That is, original /boh/ was pronounced [booh] in Nsg but [boh-a] in Gsg/Asg and all other inflected forms. The lengthened phonetic form was then lexicalized as /booh/ in Nsg, while the unlengthened /boh/ continued to be associated to other inflected forms. Hence the split of the single underlier into two allomorphs, /booh/ and /boh/ (see section 4.2). A suggestion regarding the factors that provoked the lexicalization of phonetic length in some lexical items but not in others comes from the list of words that phonologized phonetic length: looking at the 20 remaining roots in Modern Czech (see footnote 8) or at the Old Czech situation in (4), the words strikingly belong to something that may be called 'basic' vocabulary. That is, words like 'God', 'knife', 'table', 'house', 'ox' and 'court' phonologized length, while 'angle', 'bell', 'hunt', 'metal' or 'haystack' did not. This tendency hints at frequency as a relevant factor.

Once the phonetic length was transformed into a phonological object in lexical entries, further evolution and phonological processes applied to the respective lexical representations: /booh/ became /buuh/ when raising affected long oo, while /boh/ was not affected. The erratic lexical coverage of the alternations is due to the fact that the lexicalization of the phonetically lengthened vowel was not general but rather implemented on a case-by-case basis: it occurred for /boh/ (becoming /booh/), but not for /roh/ which was also pronounced [roof], but remained/roh/. Morpheme-specific (and hence erratic) lexicalization of a phonetic pattern thus directly produces the lexical idiosyncrasy that is found in all attested stages of the languages at hand. The alternative phonologization in terms of phonological computation 
creates regularity that will have to be made irregular according to the standard aging process of phonological rules (as per the life cycle of phonological processes).

\section{Vowel lengthening before voiced obstruents and sonorants in German strong verbs}

Germanic strong verbs are traditionally classified according to Grimm's ablaut classes that are based on the original IE root-final consonant. The root vowel of class 1 is followed by yod, class 2 is $w$-final, roots of class 3 end in LC or NC (German binden, bergen), simple liquids or nasals follow the root vowel in class 4 (German stehlen), and class 5 feature obstruents (German liegen). Of interest here is the fact that classes 1 and 2 fall into two subclasses each, as shown in (7) below for German (the record is exhaustive).

(7) German ablaut classes 1 and 2

\begin{tabular}{|c|c|c|c|c|c|c|}
\hline \multirow{2}{*}{\multicolumn{2}{|c|}{ class }} & \multicolumn{3}{|c|}{ root vowel } & \multirow{2}{*}{$\begin{array}{l}\text { stem- } \\
\text { final C }\end{array}$} & \multirow[b]{2}{*}{ members } \\
\hline & & pres. & & part. & & \\
\hline 1 & a & aj & I & I & -_ T & $\begin{array}{l}\text { sich befleißen, beißen, bleichen, gleichen, } \\
\text { gleiten, greifen, kneifen, kreischen, } \\
\text { pfeifen, reißen, reiten, scheißen, } \\
\text { schleichen, schleifen, schleißen, } \\
\text { schmeißen, schreiten, spleißen, } \\
\text { streichen, streiten, weichen }\end{array}$ \\
\hline & b & $a j$ & ii & ii & _D & $\begin{array}{l}\text { bleiben, gedeihen, leihen, meiden, } \\
\text { preisen, reiben, scheiden, schreiben, } \\
\text { schreien, schweigen, speien, steigen, } \\
\text { treiben, weisen, zeihen } \\
\text { scheinen }\end{array}$ \\
\hline 2 & a & aw / ii & 3 & כ & - $\mathrm{T}$ & $\begin{array}{l}\text { saufen, fließen, genießen, gießen, } \\
\text { kriechen, riechen, schießen, schließen, } \\
\text { sprießen, triefen, verdrießen }\end{array}$ \\
\hline & $\mathrm{b}$ & $\begin{array}{c}\mathrm{ii} / \mathrm{yy} / \\
\text { aw }\end{array}$ & 00 & 00 & __D & $\begin{array}{l}\text { biegen, bieten, erkiesen, fliegen, fliehen, } \\
\text { schieben, stieben, wiegen, ziehen, lügen, } \\
\text { trügen, saugen, schnauben } \\
\text { frieren, verlieren, küren }\end{array}$ \\
\hline
\end{tabular}

Subclasses are defined by the length of the root vowel in the preterite and the past participle: short I and $\supset$ are characteristic for classes $1 \mathrm{a}$ and $2 \mathrm{a}$, respectively, while long ii and oo are characteristic of classes $1 \mathrm{~b}$ and $2 \mathrm{~b}$, respectively. Hence gleiten $\sim$ gl[I]tt $\sim$ gegl[I]tten (1a), saufen $\sim$ s[ग]ff $\sim$ ges[ग]ffen (2a), but bleiben $\sim$ bl[ii] $b \sim$ gebl[ii]ben (1b), biegen $\sim b[0 o] g \sim$ geb[oo]gen (2b). As may be seen, short root vowels in the preterite and past participle $(1 \mathrm{a}, 2 \mathrm{a})$ are followed by voiceless 
obstruents, while long root vowels $(1 \mathrm{~b}, 2 \mathrm{~b})$ precede voiced obstruents and sonorants. ${ }^{10}$

We are therefore facing the same distribution as in the Western Slavic pattern: long vowels go along with following sonorants and voiced obstruents, while short vowels are followed by voiceless obstruents.

\section{English}

\subsection{Distribution of extra length}

In English, vowels are lengthened before sonorants and voiced obstruents. English has short and long (or tense and lax) vowels, which are both significantly longer phonetically when occurring before sonorants and voiced obstruents. That is, short vowels are longer and long vowels are extra-long in this context. This is shown under (8) below (data are adapted from Pöchtrager 2006, 18) where phonemic length is indicated by repeating the vowel, while extra length is marked by ':'.

(8) English: phonetic lengthening of short and long vowels

\begin{tabular}{|c|c|c|c|c|c|c|c|c|}
\hline & \multicolumn{4}{|c|}{ short (lax) vowels } & \multicolumn{4}{|c|}{ long (tense) vowels } \\
\hline & \multicolumn{2}{|c|}{$-\mathrm{T}$} & \multicolumn{2}{|c|}{ - D, R } & \multicolumn{2}{|c|}{$-\mathrm{T}$} & \multicolumn{2}{|c|}{ D, R } \\
\hline$\_p, b$ & rip & rıp & $r i b$ & risb & loop & luup & lube & luu:b \\
\hline$f_{f}, \mathrm{v}$ & stiff & stIf & live & lisv & leaf & liif & leave & lii:v \\
\hline _t,d & bit & bit & bid & brid & beat & biit & bead & bii:d \\
\hline _k,g & & sik & & brig & beak & biik & league & lii:g \\
\hline$\_s, \mathrm{Z}$ & hiss & his & his & hI:z & (a) use & juus & (to) use & juu:z \\
\hline$-n$ & & & bin & br:n & & & bean & bii:n \\
\hline m & & & $\operatorname{dim}$ & di:m & & & deem & dii:m \\
\hline _l & & & bill & bril & & & peel & piill \\
\hline
\end{tabular}

The phonetic literature provides extensive study and description of the phenomenon: among many others, see Rositzke (1939), Peterson \& Lehiste (1960), House (1961), Raphael (1972), Laeufer (1992), van

\footnotetext{
${ }^{10}$ Leiden $\sim$ l[I]tt $\sim$ gel[I]tten, schneiden $\sim$ schn[I]tt $\sim$ geschn[I]tten and sieden $\sim$ s[J]tt $\sim$ ges[J]tten have a short vowel in the preterite / participle and should therefore display a voiceless root-final consonant. This is not the case in present tense where a d occurs, which then however appears as $t$ in the preterite and the participle. Therefore these three items are in fact regular from the point of view of the two ablaut degrees that produce the vowel length contrast: their stem-final $t$ induces shortness. The three verbs at hand are the only ones whose stem-final consonant displays different voice values across ablaut degrees.
} 
Santen (1992), Gonet \& Stadnicka (2006). The effect of sonorants and voiced obstruents on preceding vowel length is documented throughout, although this is not the only factor: morpho-syntactic divisions, place and manner of articulation also play a role (Peterson \& Lehiste 1960, Klatt 1973, Crystal \& House 1988).

\section{2 (Canadian) raising: shortening instead of lengthening, phonological rather than phonetic?}

The regular interpretation is that the phenomenon is phonetic in kind, and lengthens vowels before sonorants and voiced obstruents. House (1961) introduces the idea that the conditioning is the reverse: he interprets the process as a shortening before voiceless obstruents. Since shortening is associated to phonology but the phenomenon at hand is considered phonetic in kind, in the 1980s UCL phoneticians coined the term 'pre-fortis clipping' for the process at hand, as John Wells explains on his blog (Wells 2010).

A question to ask regarding the shortening perspective is where the extra length that is supposed to be clipped comes from in the first place. Stress is an obvious candidate: only stressed vowels show voiceinduced modulations of duration. That is, stress lengthens vowels (a universal phonetic effect), and this extra length is then inhibited by a following voiceless obstruent.

Based, on the clipping analysis, Bermúdez-Otero (2014) goes one step further, arguing that the process is phonological in kind, rather than phonetic. His arguments are not based on the actual differences in vowel duration, though, but on a secondary effect thereof that is observed in a number of varieties of English where the diphthong ar is raised to $\Lambda \mathrm{i}$ before voiceless obstruents. The most well-known case in the literature is found in Ontario and known as Canadian Raising (Chambers 1973, 2006). Hence ride is pronounced r[aI]de, but write appears as wr[ni]te. Infamously, Canadian Raising (and all other varieties that exhibit this kind of raising, as Bermúdez-Otero 2014 reports) interacts opaquely with t-flapping whereby flapping counterbleeds raising. ${ }^{11}$ Hence in writer the t first raises the preceding vowel to $\Lambda \mathrm{i}$ and then undergoes flapping, resulting in wr[nir]er. Rider on the other hand also undergoes flapping, but not raising, and therefore appears as r[aIr]er. The argument made by Bermúdez-Otero (2014), then, is that

\footnotetext{
11 Joos (1942) has aired the description of a 'dialect B' of Canadian English where the interaction is transparent, i.e. the rule order reversed. This was then taken to be the crucial argument for extrinsic rule ordering by Bromberger \& Halle (1989), but unfortunately dialect B has never actually existed (Kaye 1990).
} 
raising, and hence the influence of voiceless obstruents on the preceding vowel through pre-fortis clipping, must be phonological in kind since it opaquely interacts with t-flapping, which no doubt is phonological. That is, a phonological process (t-flapping) has no access to phonetic information (in a modular environment) and therefore could not possibly be conditioned by pre-fortis clipping if clipping were phonetic in kind.

Another argument made by Bermúdez-Otero (2014) is the fact that raising is categorical, rather than gradient, and hence belongs to the realm of phonology. Finally, a third argument concerns the impact of morphological effects on raising, which according to Bermúdez-Otero's view can occur only in the phonology. Relevant contexts are shown in (9) below (from Bermúdez-Otero 2014).

(9) Contexts for Canadian Raising

\begin{tabular}{|c|c|c|c|c|}
\hline word & raising? & pronunciation & $\mathrm{T}$ belongs to & $\begin{array}{l}\text { diphthong } \\
\text { stressed? }\end{array}$ \\
\hline \multirow{3}{*}{$\begin{array}{l}\text { a. cíte } \\
\text { cýcle } \\
\text { nítrate }\end{array}$} & yes & $\mathrm{c}[\Lambda \mathrm{i}] \mathrm{t}$ & the same morpheme & yes \\
\hline & yes & $\mathrm{c}[\Lambda \mathrm{i}] \mathrm{cle}$ & the same morpheme & yes \\
\hline & yes & $\mathrm{n}[\Lambda \mathrm{i}]$ trate & the same morpheme & yes \\
\hline b. citátion & no & $c[a r]$ tation & the same morpheme & no \\
\hline c. éye-ful & no & [aI]e-ful & a different morpheme & yes \\
\hline d. tíe shop & no & $\mathrm{t}[\mathrm{a} \mathrm{I}] \mathrm{e}$ shop & a different morpheme & yes \\
\hline
\end{tabular}

Bermúdez-Otero concludes that raising is a stem-level (i.e. class 1) process since it does not apply when the voiceless obstruent belongs to a word-level suffix (i.e., class 2, éye-ful) or across word boundaries (tíe shop). What is missing in the data, though, is a case where the following voiceless obstruent belongs to a stem-level affix. According to Bermúdez-Otero's analysis, raising should apply in this context, which however will be hard or impossible to come by since relevant words need to involve a diphthong-final stem followed by a T-initial class 1 affix. Unfortunately, though, class 1 affixes are all vowel-initial.

\subsection{Phonetic influence of voicing, phonologization of the result, then phonological raising}

There is an alternative empirical generalization prompted by the data in (9), however, which is much simpler and does not involve affix classes. That is, raising occurs only when two conditions are met: the T following the diphthong must belong to the same morpheme, and the 
diphthong must be stressed. If either condition is not fulfilled, raising does not occur.

What that means is that there is no morphological conditioning: setting stress aside for the time being, the only conditioning factor is tautomorphematicity of the diphthong and the T. In other words, raising may be simply recorded in the lexicon: the lexical representation of each morpheme contains the information that qualifies for raising. Morpho-syntactic structure created during the actual derivation is then entirely transparent. Hence the stem write is recorded as / $\mathrm{rai}_{\mathrm{x}} \mathrm{t} /$ while the lexical representation of ride is /raid/: subscript $\mathrm{x}$ in the former denotes the lexical property of the diphthong that will cause raising, on which more below.

The only factor that conditions raising and is absent from the lexicon, then, is stress. There can be no doubt that stress is phonological in kind, and hence that raising occurs in the phonology. But this does not mean that the bearing of consonant voicing on the diphthong (whether lengthening or shortening) is also a phonological process. The gist of Bermúdez-Otero's (2014) analysis is the insight that pre-fortis clipping and raising are two distinct processes: first pre-fortis clipping shortens the diphthong (at the stem level cycle), then there is contextfree raising of all and only those diphthongs that have been clipped. On this analysis, clipping opaquely interacts with t-flapping, but the raising process itself is entirely transparent (and context-free).

Bermúdez-Otero holds that both processes, clipping and raising, are phonological in kind. This is not the only option, though: clipping may be phonetic, while raising may occur in the phonology and only targets stressed diphthongs. Bermúdez-Otero reports that the phonetic literature has identified a phonetic precursor of raising: so-called offglide peripheralization, which occurs in all varieties investigated that have raising (Thomas 2000, Moreton \& Thomas 2007). This process is gradient and hence attributed to the phonetics: it turns the (diachronically) original [aI] into [ai] before voiceless obstruents. The derivation of write is thus wr[ar]t $\rightarrow \mathrm{wr}[\mathrm{ai}] \mathrm{t} \rightarrow \mathrm{wr}[\Lambda \mathrm{i}] \mathrm{t}$. The bearing of voicing on the diphthong is thus phonetic in kind, not phonological. The result may then be phonologized through lexicalization, so that the underlying representation that enters a phonological derivation contains [ai] before voiceless obstruents (write is /rait/), but [ar] when followed by sonorants and voiced obstruents (ride is /raid/). Offglide peripheralization thus produces the subscript $\mathrm{x}$ in the above / $\mathrm{rai}_{\mathrm{x}} \mathrm{t} /$, which is lexicalized. Phonological computation then operates raising through a process that turns stressed ai into $\Lambda \mathrm{i}$. This scenario is depicted under (10) below. 
(10) (Canadian) raising

a. diachronic phonetics step 1

offglide peripheralization

[ar] > [ai] before voiceless

r[ar]de wr[ai]te

obstruents

b. diachronic phonologistep $2 \quad$ zation

restructuring of the lexical

r/aI/de wr/ai/te entry; all morphemes where

[ai] is pronounced are

recorded as /ai/

c. diachronic phonology raising through phonological r/ai/de wr/si/te step 3

computation

$/ \mathrm{ai} / \rightarrow / \Lambda \mathrm{i} /$ if stressed

Recall that there is no morpho-syntactic factor that conditions raising: stress is the only conditioning property that is not recorded in the lexicon. Hence both cíte and citátion are recorded with an /ai/ in the lexicon, but only the diphthong of cíte will be raised: in cit-átion it is not stressed.

As a result, raising itself is a phonological process, but the operation that alters the vowel quality according to the voicing of the following consonant is not: documented evidence from offglide peripheralization shows that it is a truly phonetic effect. The opaque interaction of raising and t-flapping then occurs in the phonology, and raising is categorical because it is phonological in kind.

Note that this analysis parallels the Slavic pattern in that the effect of the phonetic voice-induced modification of the vowel only becomes really visible when it is phonologized, i.e., enters the lexical recording of morphemes and is then further manipulated by a phonological process. This process is actually raising in both cases: oo $\rightarrow$ uu (and ą $\rightarrow$ ę) in Slavic, stressed ai $\rightarrow \Lambda$ in English.

Given the analysis in (10), the initial chicken-and-egg question is posed anew: is the active phonetic agent voicing or voicelessness? Are we facing lengthening before sonorants and voiced obstruents, or shortening (clipping) before voiceless obstruents? In the English case, the scenario based on lengthening holds that there is a general (context-free) process of offglide peripheralization that was inhibited before sonorants and voiced obstruents. On the assumption of shortening, offglide peripheralization is caused by voiceless obstruents.

The discussion of the cross-linguistic situation in section 7 will speak to this issue.

\subsection{Unwarranted consequences if voicing affects vowels in the phonology}

If not only raising but also voice-induced vowel modification is phonological, four distinct phonological objects must be recognized: 
short/lax vowels with and without extra length and long/tense vowels with and without extra length. This is embarrassing since of course there is no four-way contrast in vowel length in natural language. Hence the basic distinction could be tense vs. lax (rather than long vs. short), meaning that both types of vowels are associated to one single $\mathrm{x}$ slot (or mora or whatever other unit of syllabic space). Extra length then is the result of the insertion of another x-slot which produces the four categories tense long, tense short, lax long and lax short. This scenario thus implements lengthening. If on the other hand shortening (pre-fortis clipping) is to be represented, one would need to assume that all vowels are long in English and lose an x-slot when followed by a voiceless obstruent.

In both cases, the causality is quite outlandish: the feature [spread glottis] (or whatever prime representing voicing is used) will have to either give birth to or eliminate an x-slot. In the case of lengthening before sonorants and voiced obstruents, the questionable specification of sonorants for phonologically active voicing is needed on top of that. On the assumption of shortening (pre-fortis clipping), this issue does not arise: only a regular phonological prime responsible for voicelessness in obstruents is needed. English being an aspiration language (see section 3), [spread glottis] is present in voiceless obstruents and can be said to be responsible for the insertion of an $\mathrm{x}$ slot in the phonology.

Transforming voicing into an x-slot or having it eliminate one does not look like anything phonology should or could do, however. But still the four categories have to be somehow represented if the process is phonological. Bermúdez-Otero (2014) proposes that voiceless obstruents are linked to the preceding vowel, as in (11) below.

$\begin{array}{cccc}\text { bid } & & \text { bit } \\ \mathrm{I} & \mathrm{x} & \mathrm{d} & \mathrm{I} \\ \mathrm{I} & \mathrm{d} & \mathrm{t}\end{array}$
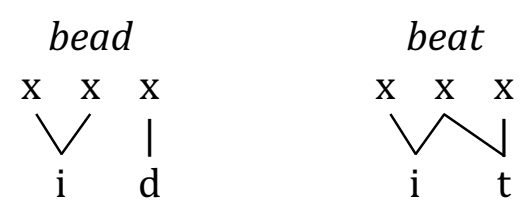

The effect of a consonant being linked to a vocalic constituent is then to shorten the vowel that is attached to this constituent. Bermúdez-Otero calls this durational trade-off, but it is not clear which duration is traded against which other duration: phonological voicelessness has nothing to do with any duration that could be traded. Also, it is not clear what it means for a consonant to be linked to a nucleus: a basic autosegmental principle is that consonanthood and vowelhood are not specified in the melodic makeup of segments (as was the case in SPE), but rather follow from their syllabic affiliation. That is, a set of melodic primes is 
pronounced as a vowel when associated to a nucleus, but as a consonant when occurring in an onset/coda.

Facing this impossibility to phonologically represent the voice-tolength causality with standard tools, Pöchtrager (2006) and Pöchtrager \& Kaye (2013) take a more radical step. Like Bermúdez-Otero, they consider that voice-induced length is phonological in kind. The English pattern is a central motivation for the new representational theory they introduce, GP2.0 (an outgrowth of Government Phonology). This approach does away with the melodic representation of voicing, precisely in order to make its interaction with segmental length viable: if voicing is able to cause modifications of length, and if length is a matter of the number of $x$-slots a unit is attached to, then the phonological identity of voicing must itself be cast in terms of $\mathrm{x}$-slots. Hence in their system voiced obstruents are phonologically short (one $\mathrm{x}$-slot), while voiceless obstruents are long (two x-slots). A V̆C stretch then represents three $\mathrm{x}$-slots, to the effect that there is only one left for the $\mathrm{V}$ before voiceless obstruents, while the vowel may occupy two $\mathrm{X}$ slots before voiced obstruents. This perspective where the $\mathrm{V}$ and the $\mathrm{C}$ compete for a piece of duration also has a phonetic version: "a longer intervening consonant must 'borrow' duration from the preceding vowel" (Maddieson 1996, 165). On Pöchtrager \& Kaye's analysis, the phonetic pattern is transferred into the phonology.12

This all shows that accommodating voice-induced vowel length in the phonology comes at a significant cost that is not incurred if it is phonetic in kind, as suggested above.

\section{Cross-linguistic generalizations and phonologization}

\subsection{Generalizations, Laryngeal Realism and the lengthening vs. shortening question}

The longer duration of vowels before voiced obstruents and sonorants, as compared to voiceless items, is a massive cross-linguistic generalization. ${ }^{13}$ It is therefore held to be universal, i.e., the result of

\footnotetext{
12 A consequence of this move is that $\mathrm{x}$-slots are quite different from what phonologists usually refer to as timing units: voiceless obstruents are 'geminates' and phonetically lengthened vowels that are phonemically short occupy two units (just like phonemically long vowels that receive no phonetic extra length), while their phonemically long congeners encompass 3 slots.

${ }^{13}$ Beyond the references mentioned above, the body of literature regarding individual languages or cross-linguistic studies includes Belasco $(1953,1958)$, Hoffman (1958), Zimmermann \& Sapon (1958), Delattre (1962), Hogan \& Rozsypal (1980), Luce \& Luce (1985), Kluender (1988), van Santen (1992).
} 
speech production (which is referred to as mechanical, automatic, physiological or inherent to articulation: Delattre 1962, Chen 1970, Maddieson 1996, 164f, 1999). It is often mentioned that the difference in vowel length before voiced and voiceless consonants is greater in English than in other languages, and there is debate whether the pattern is truly universal: Mitleb (1984) and Keating (1979) found that there is no effect in Jordanian Arabic and Polish/Czech, respectively.

Whether universal or not, whether learned during L1 acquisition or a mechanical consequence of speech production, and whatever the cause of the pattern (Maddieson 1996, 164ff, 1999 reviews relevant positions), it is undisputed that there is a correlation between vowel duration and the voicing of following consonants. Specifically, the three generalizations under (12) are of interest.

(12) Generalizations regarding voice-induced variation of vowel duration

a. Extra duration goes with voicing, not with voicelessness

If anything, vowel duration is greater before voiced than before voiceless consonants. The reverse pattern whereby vowels are longer before voiceless than before voiced consonants is unheard of.

b. Sonorants always side with voiced obstruents

In all cases that I have come across in the literature, extra duration occurs before voiced obstruents and sonorants. There are no instances where extra length is found before voiced obstruents, but not before sonorants. Note that studies sometimes talk about 'voiced consonants' without making explicit whether sonorants are included or not.

c. Directionality

The literature only reports cases where vowel duration is increased due to a following sonorant or voiced obstruent. Cases where the voicing of preceding consonants impact the duration of vowels do not seem to be on record (Peterson \& Lehiste 1960).

Unlike Cracow voicing, the Western Slavic and the German case where the voicing of sonorants and voiced obstruents is categorychanging, it is merely phonetic in English. That is, in Cracow voicing, sonorants and voiced obstruents turn a preceding voiceless into a voiced obstruent (in a system where obstruent voicing is distinctive), and in the Western Slavic and German patterns they transform a short into a long vowel (the difference being phonemic, in Western Slavic at least since oo raised to $\mathrm{uu}$ ). By contrast, the modification of the preceding vowel in English is category-neutral: the phonetic duration of short and long vowels is manipulated, but short vowels remain 
phonemically short and long vowels continue to be long. The same goes for (Canadian) raising: the original and raised diphthongs are not contrastive.

The cross-linguistic record also speaks to the question whether (in English) sonorants and voiced obstruents cause lengthening, or rather voiceless obstruents trigger shortening. The observation is that voiceinduced vowel length modification occurs in voicing as much as in aspiration languages (see section 3): Chen (1970) for example reports relevant data regarding Russian and French (voicing languages) and English (aspiration language). If voicing modifies vowel length in the phonology, voicing languages which possess only [voice] (or L) cannot possibly implement shortening (pre-fortis clipping) since this supposes that [spread glottis] (or H) causes shortening - but there is no such prime in the language. Aspiration languages on the other hand cannot feature lengthening since the prime that is responsible for voicing, [voice] (or L), is absent.

Hence if voice-induced vowel duration modification is assumed to be phonological, there need in fact to be two distinct processes: voicing languages must have lengthening, while aspiration languages implement shortening. In addition, sonorants must bear a phonologically active voicing prime in the former, which is odd anyway.

By contrast, if vowel duration is modified by phonetic voicing, there is no need to duplicate the process: voice-induced duration modification may follow the same mechanism in all languages. The issue regarding the voicing of sonorants also disappears since the phonetic voicing of sonorants will always be phonologically inactive. Finally, the shortening perspective (pre-fortis clipping) can safely be discarded. Recall that it supposes some independent source of extra length that is distributed to all vowels, whose implementation before voiceless consonants is inhibited. In the English case, a candidate for the origin of this extra length is stress. It is not the case, though, that vowels which are subject to voicing-induced duration modification are stressed in all languages. In absence of an independent source of 'spontaneous' lengthening, the shortening perspective is not viable, however.

The bottom line of all this is that the shortening scenario appears to be riddled with issues, while the analysis based on lengthening may be applied to all languages, provided lengthening is phonetic in kind. And Laryngeal Realism provides strong evidence in favour of lengthening before sonorants and voiced obstruents if the effect of voicing on preceding vowels indeed occurs in the phonetics: there is passive voicing, but there is no passive devoicing (see section 3). That is, in aspiration languages, obstruents which are phonologically unspecified 
for voicing may acquire voicing from surrounding vowels and sonorants in the phonetics (passive voicing). The reverse process whereby neutral obstruents in voicing languages acquire voicelessness from surrounding voiceless obstruents (passive devoicing) is unheard of. Hence a perspective whereby the shortening of vowels before voiceless obstruents (pre-fortis clipping) occurs in the phonetics appears to be ruled out: the insight from Laryngeal Realism is that the voicing of voiceless obstruents does not affect neighbours (while the voicing of sonorants and vowels does).

\subsection{Phonologization}

The overall picture emerging from the preceding is that an increase in vowel duration caused by following sonorants and voiced obstruents in the phonetics was phonologized in Western Slavic, German and the varieties of English that implement diphthong raising, while those varieties of English where no raising occurs remain at the preceding diachronic stage where the phonetic pattern is not (yet) imported into the phonology. Phonologization in all cases at hand means that the lexical entry of morphemes was modified according to the phonetic pattern: such a modification occurred in Western Slavic, German and the raising varieties of English, while the non-raising varieties of English exhibit unmodified lexical representations. Once the phonetic difference is recorded in the lexicon, it may serve as the input for phonological processes (such as raising in Western Slavic or English).

Note that according to the labovian perspective on language change, speakers selectively phonologize phonetic variation present (and inherent) in the signal for the purpose of group recognition (e.g., Labov 1963, 2001). Also note that the fact that the same sound pattern or process can be phonetic in one language, but phonological in another language, is well documented (Cohn 1998).

\subsection{What about the Western Slavic restriction to vowels before word-final consonants?}

Finally, let us now come back to the Western Slavic pattern. Recall that it is not just the phonologized version of the situation encountered in non-raising varieties of English: being followed by a sonorant or voiced obstruent is a necessary condition for lengthening, but it only occurs, however, if the consonant at hand is also word-final. How could phonetic duration (provided by voiced consonants in all contexts) be selectively phonologized according to what looks like a typically phonological (or rather: morphological) condition, i.e., the right edge of the word? This seems to be something that phonetics cannot do and is 
hence evidence for a stage where a phonologized version of the phonetic pattern as under (3) was active in phonological computation.

An observation by Klatt $(1973,1102)$ shows that this is not the case: the end of the word is a factor that does condition the phonetic pattern of English vowels. Klatt compared the duration of vowels in CVC (beat, stoop, glide, room) and CVCV(C) (beaten, stupid, gliding, rumour) items. He found that for each given consonant $C_{x}$, the preceding vowel in $\mathrm{CVC}_{\mathrm{x}} \#$ was significantly longer than in $\mathrm{CVC}_{\mathrm{x}} \mathrm{V}(\mathrm{C})$. He further reports that the difference in duration between vowels followed by word-final and internal consonants is significantly higher when the consonant is a sonorant or a voiced obstruent, as compared to voiceless obstruents. Hence the duration of the vowel in beaten is $97 \%$ of the duration of the vowel in beat, and this ratio goes down to $80 \%$ for the pair trashy trash. But voiced consonants produce far lower ratios: the vowels in gliding and rumour make only $72 \%$ and $61 \%$ of the vowels in glide and room, respectively.

Hence English implements both conditions of the Western Slavic pattern in the phonetics: vowel duration is significantly higher before voiced consonants that are word-final, as compared to word-final voiceless consonants. Or, put differently, of all contexts, vowels have the highest duration before word-final voiced consonants. If the English pattern is indicative of the Western Slavic situation, what was phonologized in the latter is thus a simple phonetic pattern: only vowels with the highest duration were considered as long vowels and implemented as such in the lexicon.

This supports the above analysis where the process was never present in phonological computation of any diachronic stage: phonetic lengthening was phonologized in such a way that duration was recorded in the lexical entry of individual words. This lexicalization covered the lexicon in an arbitrary way and triggered an allomorphic management of ensuing alternations. This scenario skips the phonological computation stage of the canonical life cycle. It is based in the idea that spontaneous and non-spontaneous voicing are truly waterproof, i.e., that the voicing of sonorants and vowels is irrelevant and invisible for phonological computation.

\section{Conclusion}

If voice-induced lengthening is phonetic in kind, a prediction is made that a pattern where this process is triggered by voiced obstruents, but not by sonorants, cannot exist. This is because the voicing of voiced obstruents and the voicing of sonorants is indistinguishable in the phonetics. The distinction can only be made in the phonology. Hence for 
such cases, should they exist, the phonetic perspective is refuted. If they are not on record despite the massive documentation of the phenomenon, though, strong evidence is provided in favour of the fact that voice-induced lengthening can only be phonetic in kind. It was mentioned in $(12 \mathrm{~b})$ that no such cases seem to be reported in the literature.

This empirical situation contrasts with the one that is found for the other voice-induced process that was discussed: the assimilation of voiceless obstruents to the voicing of following vowels, sonorants and voiced obstruents, as in Cracow voicing. In this case there is an obvious and trivial version of the process where triggers are restricted to voiced obstruents. For example, the external sandhi voicing that occurs in Warsaw Polish is exactly like the one that was described for CracowPoznań, except that word-final voiceless obstruents only voice when followed by a voiced obstruent: vowels and sonorants have no effect. Beyond that, patterns where in a sequence of two obstruents the second imposes its voice value on the first (but where sonorants and vowels have no effect) are ubiquitous across languages.

Table (13) below summarizes the contrast at hand.

\begin{tabular}{lcc} 
& \multicolumn{2}{c}{ trigger } \\
& $\begin{array}{c}\text { sonorants and } \\
\text { voiced obstruents }\end{array}$ & $\begin{array}{c}\text { only voiced } \\
\text { obstruents }\end{array}$ \\
$\begin{array}{l}\text { a. lengthening of a preceding } \\
\text { vowel }\end{array}$ & yes & no \\
$\begin{array}{l}\text { b. voicing of a preceding } \\
\text { voiceless obstruent }\end{array}$ & yes & yes
\end{tabular}

On the assumption that voice transmission occurs in the phonology, there is no reason why the set of triggers should not be able to be restricted to just voiced obstruents: we would expect languages where vowel lengthening occurs before voiced obstruents, but not before sonorants. Their absence in the case of voice-induced vowel lengthening (or at least the fact they are not as easy to come by as the parallel voice assimilation of obstruents), strongly suggests that voiceinduced vowel lengthening is never phonological in kind. In fact, that it could not possibly be phonological.

On the other hand, if voice-induced vowel lengthening is only ever phonetic, the absence of cases where only voiced obstruents are triggers is predicted: in the phonetics any articulation that is produced with vibrating vocal folds counts as voiced, and phonetics is unable to distinguish subsets of these articulations. On this analysis, Cracow 
voicing is also phonetic in kind, since again any surface voicing triggers the process. By contrast, regular voice assimilation among obstruents that is not triggered by sonorants (such as in Warsaw Polish) is phonological: only obstruents have phonologically active voicing and therefore only their voicing can be transmitted by a phonological process.

Unless one is ready to make the unreasonable assumption that voice-induced vowel lengthening and the Cracow-type assimilation of obstruents are entirely distinct processes that do not share anything, it follows that voice-induced vowel lengthening is also phonetic in kind. If one process that is triggered by the voicing of sonorants and voiced obstruents is demonstrably phonetic, so must be the other process that is triggered by the same items.

Note that the overall phonetic perspective on voice-induced vowel lengthening and the Cracow-type obstruent assimilation has the enjoyable consequence of making spontaneous and non-spontaneous voicing truly waterproof: sonorants and vowels are never phonologically specified for voicing, and the only way to carry their voicing into the phonology is through phonologization.

Finally, in cases like the non-raising varieties of English where the modification of vowels is not category-changing or exploited by a phonological process (such as raising), it is hard to see why one would want to locate the duration-producing mechanism in the phonology. The above argument regarding the absence of cases where only voiced obstruents trigger a process will need to be addressed, and sonorants will have to be phonologically specified for voice in a context where the phonetics does the entire job and we know that phonological categories are not involved. Also, the addition (or elimination/inhibition) of an extra phonological timing unit (x-slot, mora, CV unit etc.) provoked by a segmental property such as voicing is outlandish and certainly nothing that any phonological theory can do or will want to do. Except, of course, if voicing is removed from the segmental realm and represented in terms of length, as in GP2.0. This move comes at the costs mentioned and needs to be motivated, though: why should we duplicate in the phonology what phonetics gives us anyway? This is what Hale \& Reiss (2000) call substance abuse. 


\section{Comments invited}

PiHPh relies on post-publication review of the papers that it publishes. If you have any comments on this piece, please add them to its comments site. You are encouraged to consult this site after reading the paper, as there may be comments from other readers there, and replies from the author. This paper's site is here:

https://doi.org/10.2218/pihph.2.2017.1910

\section{Author contact details}

\section{Tobias Scheer}

Université Côte d'Azur, CNRS

Bases Corpus Langage (BCL)

24, avenue des Diables Bleus

F-06300 Nice

France

scheer@unice.fr

\section{References}

Avery, Peter \& William Idsardi. 2001. Laryngeal dimensions, completion and enhancement. In Tracy Hall (ed.), Distinctive feature theory, 41-70. Berlin: Mouton de Gruyter.

Baudouin de Courtenay, Jan Niecisław. 1895. Versuch einer Theorie phonetischer alternationen. Ein Capitel aus der Psychophonetik. Straßburg: Trübner.

Belasco, Simon. 1953. The influence of force of articulation of consonants on vowel duration. The Journal of the Acoustical Society of America 25. 1015-1016.

Belasco, Simon. 1958. Variations in vowel duration: phonemically or phonetically conditioned? The Journal of the Acoustical Society of America 30. 1049-1050.

Bermúdez-Otero, Ricardo. 2006. Phonological domains and opacity effects: a new look at voicing and continuancy in Catalan. Paper presented at the Workshop on Approaches to phonological opacity at GLOW, Barcelona, April, 5th.

Bermúdez-Otero, Ricardo. 2014. The diachronic rise and synchronic representation of phonological opacity: a case study. Paper presented at RALFe, Paris, 9th October.

Bermúdez-Otero, Ricardo. 2015. Amphichronic explanation and the life cycle of phonological processes. In Patrick Honeybone \& Joseph C. 
Salmons (eds.), The Oxford handbook of historical phonology, 374399. Oxford: OUP.

Bethin, Christina. 1979. Morphology in phonology: the case of syllabic lengthening in Polish and Slovak. Glossa 13. 251-262.

Bethin, Christina. 1984. Voicing assimilation in Polish. International Journal of Slavic Linguistics and Poetics 29. 17-32.

Bethin, Christina. 1992. Polish syllables: the role of prosody in phonology and morphology. Columbus OH: Slavica.

Bethin, Christina. 1998. Slavic prosody: language change and phonological theory. Cambridge: Cambridge University Press.

Boersma, Paul. 1998. Functional phonology: formalizing the interactions between articulatory and perceptual drives. The Hague: Holland Academic Graphics.

Botma, Bert 2004. Phonological Aspects of Nasality. An Element-Based Dependency Approach. Ph.D dissertation, University of Amsterdam.

Botma, Bert. 2011. Sonorants. In Marc van Oostendorp, Colin J. Ewen, Elizabeth Hume \& Keren Rice (eds.), The Blackwell Companion to Phonology, 171-194. New York: Wiley-Blackwell.

Botma, Bert \& Norval Smith. 2006. A dependency account of the fortislenis contrast in Cama. In Jeroen van de Weijer \& Bettelou Los (eds.), Linguistics in the Netherlands 2006, 15-27. Amsterdam: Benjamins.

Bromberger, Sylvain \& Morris Halle. 1989. Why phonology is different. Linguistic Inquiry 20. 5170.

Carlton, Terence. 1991. Introduction to the phonological history of the Slavic languages. Columbus, Ohio: Slavica.

Chambers, J. K. 1973. Canadian raising. Canadian Journal of Linguistics 18. 113-135.

Chambers, J. K. 2006. Canadian raising: retrospect and prospect. Canadian Journal of Linguistics 51. 105-118.

Chen, Matthew. 1970. Vowel length variation as a function of the voicing of the consonant environment. Phonetica 22.129-159.

Chomsky, Noam \& Morris Halle. 1968. The sound pattern of english. Cambridge, Mass.: MIT Press.

Clements, George \& Sylvester Osu. 2002. Explosives, implosives and nonexplosives: the linguistic function of air pressure differences in stops. In Carlos Gussenhoven \& Natasha Warner (eds.), Laboratory phonology 7, 299-350. Berlin: Mouton de Gruyter.

Cohn, Abigail. 1998. The phonetics-phonology interface revisited: where's phonetics? Texas Linguistic Forum 41. 25-40.

Crystal, T. H. \& Arthur S. House. 1988. Segmental durations in connected-speech signals: current results. Journal of the Acoustical Society of America 83. 1553-1573. 
Cyran, Eugeniusz. 2011. Laryngeal realism and laryngeal relativism: two voicing systems in Polish? Studies in Polish Linguistics 6. 45-80.

Cyran, Eugeniusz. 2012. Cracow sandhi voicing is neither phonological nor phonetic. It is both phonological and phonetic. In Eugeniusz Cyran, Bogdan Szymanek \& Henryk Kardela (eds.), Sound, structure and sense. studies in memory of Edmund Gussmann, 153-184. Lublin: Wydawnictwo KUL.

Cyran, Eugeniusz. 2014. Between phonology and phonetics. polish voicing. Berlin: Mouton de Gruyter.

De Schutter, G. \& J. Taeldeman. 1986. Assimilatie van stem in de zuidelijke Nederlandse dialekten. In M. Devos \& J. Taeldeman (eds.), Vruchten van z'n akker: opstellen van (oud-) medewerkers en oudstudenten voor Prof. V.F. Vanacker, 91-133. Ghent: Seminarie voor Nederlandse Taalkunde.

Delattre, Pierre. 1962. Some factors of vowel duration and their crosslinguistic validity. The Journal of the Acoustical Society of America 34. 1141-1143.

Długosz-Kurczabowa, Krystyna \& Stanisław Dubisz. 1993. Gramatyka historyczna języka polskiego. Pochodzenie języka polskiego, Fonetyka, Fonologia. Warszawa: Wydawnictwa Uniwersytetu Warszawskiego.

Gebauer, Jan. 1963 [1894]. Historická mluvnice jazyka českého Díl I: Hláskosloví. Praha: Nakladatelství československé Akademie Vĕd.

Gonet, Wiktor \& Lidia Stadnicka. 2006. Vowel clipping in English. Speech and Language Technology 8. 77-86.

Grzegorczykowa, Renata, Roman Laskowski \& Henryk Wróbel (eds.). 1999. Morfologia. 3rd edition Warszawa: PWN.

Gussenhoven, Carlos \& Haike Jacobs. 2011. Understanding phonology. Third edition. London: Hodder.

Gussmann, Edmund. 1980. Studies in abstract phonology. Cambridge Mass.: MIT Press.

Gussmann, Edmund. 1992. Resyllabification and delinking: The case of Polish voicing. Linguistic Inquiry 23. 29-56.

Gussmann, Edmund. 2007. The phonology of Polish. Oxford: Oxford University Press.

Hale, Mark \& Charles Reiss. 2000. Substance abuse and dysfunctionalism: current trends in phonology. Linguistic Inquiry 31. 157-169.

Hamann, Silke. 2011. The phonetics-phonology interface. In Nancy Kula, Bert Botma \& Kuniya Nasukawa (eds.), The Continuum Companion to Phonology, 202-224. London: Continuum.

Hamann, Silke. 2014. Phonetics-phonology mismatches. Paper presented at Old World Conference in Phonology, Leiden, 22-25 January. 
Harris, John. 1994. English sound structure. Oxford: Blackwell.

Harris, John. 1996. Phonological output is redundancy-free and fully interpretable. In Jacques Durand \& Bernard Laks (eds.), Current trends in phonology: models and methods, 305-332. Salford, Manchester: ESRI.

Harris, John \& Geoff Lindsey. 1995. The elements of phonological representation. In Jacques Durand \& Francis Katamba (eds.), Frontiers of phonology, 34-79. Harlow, Essex: Longman.

Hoffman, Howard S. 1958. Study of some cues in the perception of the voiced stop consonants. The Journal of the Acoustical Society of America 30. 1035-1041.

Hogan, John T. \& Anton J. Rozsypal. 1980. Evaluation of vowel duration as a cue for the voicing distinction in the following word-final consonant The Journal of the Acoustical Society of America 67. 1764-1770.

Honeybone, Patrick. 2002. Germanic obstruent lenition: some mutual implications of theoretical and historical phonology. Ph.D dissertation, University of Newcastle upon Tyne.

Honeybone, Patrick. 2005. Diachronic evidence in segmental phonology: the case of laryngeal specifications. In Marc van Oostendorp \& Jeroen van de Weijer (eds.), The internal organization of phonological segments, 319-354. Berlin: de Gruyter.

House, Arthur S. 1961. On vowel duration in english. The Journal of the Acoustical Society of America 33.1174-1179.

Hujer, Oldřich. 1946. Úvod do dějin jazyka českého. Praha: Jednota českých filologů.

Itô, Junko \& Armin Mester. 1986. The phonology of voicing in japanese: theoretical consequences for morphological accessibility. Linguistic Inquiry 17. 49-73.

Iverson, Gregory \& Joseph Salmons. 1995. Aspiration and laryngeal representation in Germanic. Phonology 12. 369-396.

Joos, Martin. 1942. A phonological dilemma in Canadian English. Language 18. 141-144.

Kavitskaya, Darya. 2002. Compensatory lengthening: phonetics, phonology, diachrony. New York \& London: Routledge.

Kaye, Jonathan. 1990. What ever happened to dialect B? In Joan Mascaró \& Marina Nespor (eds.), Grammar in progress: GLOW essays for Henk van Riemsdijk, 259-263. Dordrecht: Foris.

Keating, Patricia A. 1979. A phonetic study of a voicing contrast in Polish. Ph.D dissertation, Brown University.

Klatt, Dennis H. 1973. Interaction between two factors that influence vowel duration. The Journal of the Acoustical Society of America 54. 1102-1104. 
Kluender, Keith R., Randy L Diehl \& Beverly A. Wright. 1988. Vowellength differences before voiced and voiceless consonants: An auditory explanation. Journal of Phonetics 16.153-169.

Komárek, Miroslav. 1969. Historická mluvnice česká I: Hláskosloví. 3rd edition Praha: SPN.

Komárek, Miroslav. 1982. Nástin fonologického vývoje českého jazyka. Parha: SPN.

Krämer, Martin. 2000. Voicing alternations and underlying representations: the case of Breton. Lingua 110. 639-663.

Labov, William. 1963. The social motivation of sound change. Word 19. 273-309.

Labov, William. 2001. Principles of linguistic change. Volume 2, Social factors. Oxford: Blackwell.

Laeufer, Christiane. 1992. Patterns of voicing-conditioned vowel duration in French and English. Journal of Phonetics 20. 411-440.

Luce, Paul A. \& Jan Charles Luce. 1985. Contextual effects on vowel duration, closure duration, and the consonant/vowel ratio in speech production. The Journal of the Acoustical Society of America 78. 1949-1957.

Maddieson, Ian. 1996. Phonetic universals. UCLA Working Papers in Phonetics 92. 160-178.

Maddieson, Ian. 1999. Phonetic universals. In William J. Hardcastle \& John Laver (eds.), The handbook of phonetic sciences, 619-639. Oxford: Blackwell.

Major, Roy C. \& Michael C. Faudree. 1996. Markedness universals and the acquisition of voicing contrasts by Korean speakers of English. Studies in Second Language Acquisition 18. 69-90.

Mitleb, Fares M. 1984. Voicing effect on vowel duration is not an absolute universal. Journal of Phonetics 12. 23-27.

Moreton, Elliott \& Erik R. Thomas. 2007. Origins of Canadian Raising in voiceless-coda effects: a case study in phonologization. In Jennifer Cole \& José Ignacio Hualde (eds.) Laboratory Phonology 9, 37-63. Berlin: Mouton de Gruyter.

Pedersen, Holger. 1905. Die nasalpräsentia und der slavische akzent. Zeitschrift für vergleichende Sprachforschung 38. 297-425.

Peterson, Gordon E. \& Ilse Lehiste. 1960. Duration of syllabic nuclei in English. The Journal of the Acoustical Society of America 32. 693-703.

Piggott, Glyne. 1992. Variability in feature dependency: the case of nasality. Natural Language and Linguistic Theory 10. 33-78.

Pöchtrager, Markus 2006. The structure of length. Ph.D dissertation, University of Vienna.

Pöchtrager, Markus Alexander \& Jonathan Kaye. 2013. GP2.0. SOAS Working Papers in Linguistics and Phonetics 16. 51-64. 
Raphael, Lawrence J. 1972. Preceding vowel duration as a cue to the perception of the voicing characteristic of word-final consonants in American English. Journal of the Acoustical Society of America 51. 1296-1303.

Rice, Keren. 1993. A reexamination of the feature [Sonorant]: the Status of 'sonorant obstruents'. Language 69. 308-344.

Rice, Keren \& Peter Avery. 1989. On the interaction between sonorancy and voicing. Toronto Working Papers in Linguistics 10. 65-82.

Ringen, Catherine \& Vladimir Kulikov. 2012. Voicing in Russian stops: cross-linguistic implications. Journal of Slavic Linguistics 20. 269-286.

Rositzke, Harry A. 1939. Vowel-Length in General American speech. Language 15. 99-109.

Rospond, Stanisław. 1979. Gramatyka historyczna języka polskiego. Warszawa: PWN.

Rubach, Jerzy. 1984. Cyclic and lexical phonology: the structure of Polish. Dordrecht: Foris.

Rubach, Jerzy. 1996. Nonsyllabic analysis of voice assimilation in Polish. Linguistic Inquiry 27. 69-110.

Sanders, Robert Nathaniel. 2003. Opacity and sound change in the Polish lexicon. Ph.D dissertation, University of California at Stanta Cruz.

Scheer, Tobias. 2014. Spell-out, post-phonological. In Eugeniusz Cyran \& Jolanta Szpyra-Kozlowska (eds.), Crossing phonetics-phonology lines, 255-275. Newcastle upon Tyne: Cambridge Scholars.

Scheer, Tobias. 2015a. A world without voiced sonorants: reflections on Cyran 2014 (Part 1). Studies in Polish Linguistics 10. 125-151. Available at http://www.ejournals.eu/SPL/2015/Issue-3/art/6440/.

Scheer, Tobias. 2015b. A world without voiced sonorants: reflections on Cyran 2014 (Part 2). Studies in Polish Linguistics 10. 223-247. Available at http://www.ejournals.eu/SPL/2015/Issue-4/art/6780/.

Scheer, Tobias \& Philippe Ségéral. 2016. Actualité des néogrammairiens. Mémoires de la Société de Linguistique de Paris 23. 15-67.

Shevelov, George. 1964. A prehistory of Slavic: the historical phonology of Common Slavic. Heidelberg: Winter.

Sievers, Eduard. 1901. Grundzüge der Phonetik: zur Einführung in das Studium der Lautlehre der indogermanischen Sprachen. 5. Auflage Leipzig: Breitkopf \& Härtel.

Stieber, Zdzisław. 1958. Rozwój fonologiczny języka polskiego. 2nd edition Warszawa: PWN.

Stieber, Zdzisław. 1973. A historical phonology of the Polish language. Heidelberg: Winter.

Szpyra, Jolanta. 1989. The phonology-morphology interface. London \& New York: Routledge. 
Szpyra, Jolanta. 1992. Ghost segments in nonlinear phonology: Polish yers. Language 68. 277-312.

Szpyra, Jolanta. 1995. Three tiers in Polish and English phonology. Lublin: Wydawnictwo Universytetu Marii Curie-Skłodowskiej.

Thomas, Erik R. 2000. Spectral differences in /ai/ offsets conditioned by voicing of the following consonant. Journal of Phonetics 28. 1-25.

Timberlake, Alan. 1983. Compensatory lengthening in Slavic 1: conditions and dialect geography. In Vladimir Markov \& Dean S. Worth (eds.), From Los Angeles to Kiev: papers on the occasion of the ninth international congress of Slavists, 207-236. Columbut: Slavica.

Timberlake, Alan. 1983. Compensatory lengthening in Slavic 2: phonetic reconstruction. In Michael S. Flier (ed.), American contributions to the ninth international congress of Slavists 1: Linguistics, 293-320. Columbus: Slavica.

Trávníček, František. 1935. Historická mluvnice československá. Praha: Melantrich.

Trávníček, František. 1951. Mluvnice Spisovné Češtiny. 3rd edition Praha: Slovanské Nakladatelství.

van Santen, J. P. H. 1992. Contextual effects on vowel duration. Speech Communication 11. 513-546.

Vennemann, Theo. 1972. Sound change and markedness theory: on the history of the German consonant system. In R.P. Stockwell \& R.K.S. Macaulay (eds.), Linguistic change and generative theory: essays from the UCLA Conference on historical linguistics in the perspective of transformational theory (1969), 230-274. Bloomington: Indiana University Press.

Vondrák, Wenzel. 1924. Vergleichende slavische Grammatik. Band I: Lautlehre und Stammbildungslehre. 2. Auflage Göttingen: Vandenhoeck \& Ruprecht.

Wells, John. 2010. Pre-fortis clipping. John Wells's phonetic blog at http://phonetic-blog.blogspot.fr/2010/04/pre-fortis-clipping.html.

Wheeler, M. W. 1986. Catalan sandhi phenomena. In Henning Andersen (ed.), Sandhi phenomena in the languages of Europe, 475-488. Berlin: Mouton de Gruyter.

Zimmermann, Samuel A. \& Stanley M. Sapon. 1958. Note on vowel duration seen cross-linguistically. The Journal of the Acoustical Society of America 30. 152-153. 